\title{
Unions and Upward Mobility for Low-Wage Workers
}

John Schmitt, Margy Waller, Shawn Fremstad, and Ben Zipperer

August 2007

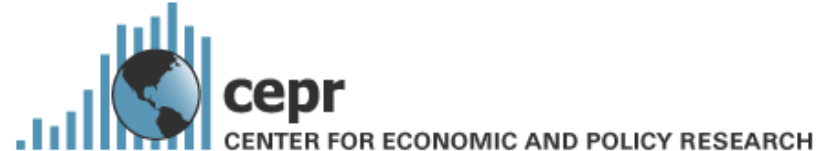

Center for Economic and Policy Research

1611 Connecticut Avenue, NW, Suite 400

Washington, D.C. 20009

202-293-5380

www.cepr.net

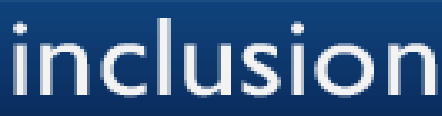

independent progressive new

Inclusion

1707 L Street NW, Suite 750

Washington, DC 20036

Phone: (202) 730-9372

www.inclusionist.org 


\section{Contents}

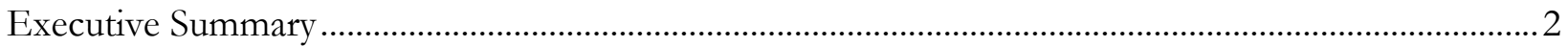

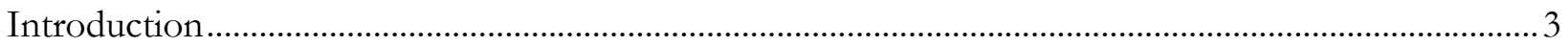

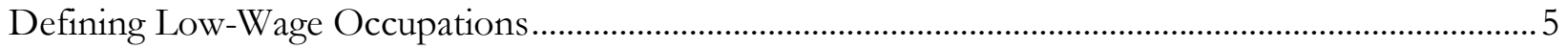

Unionized Low-Wage Jobs Pay Better and More Likely to Provide Benefits ......................................... 7

Low-Wage Jobs Improved by Worker Rights ....................................................................................

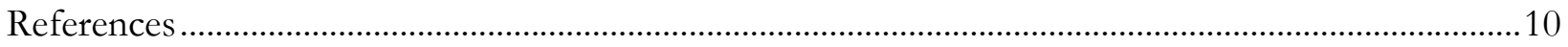

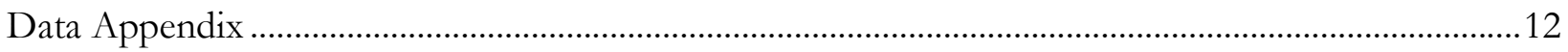

\section{About the Authors}

John Schmitt is Senior Economist and Ben Zipperer was a Research Assistant at the Center for Economic and Policy Research in Washington, DC. Margy Waller and Shawn Fremstad are cofounders of Inclusion.

\section{Acknowledgements}

The authors would like to thank Dean Baker and Heather Boushey for helpful comments. The Center for Economic and Policy Research gratefully acknowledges financial support from the Ford Foundation. 


\section{Executive Summary}

This paper examines the impact of unionization on the pay and benefits in 15 important low-wage occupations. The data suggest that even after controlling for differences between union and nonunion workers -including such factors as age and education level - unionization substantially improves the pay and benefits offered in what are otherwise low-paying occupations.

On average, in the low-wage occupations analyzed here, unionization raised workers' wages by just over 16 percent --about $\$ 1.75$ per hour-- compared to those of non-union workers.

The union impact on health-insurance and pension coverage in low-wage jobs was even bigger. Union workers were 25 percentage points more likely to have employer-provided health insurance ${ }^{1}$ and 25 percentage points more likely to be in an employer-provided pension ${ }^{2}$ than similar non-union workers in the same low-wage occupations.

These union effects are large by any measure. To put these findings into perspective, between 1996 and 2000, a period of sustained, low unemployment that helped to produce the best wage growth for low-wage workers in the last three decades, the real wage of 10th percentile workers (who make more than 10 percent of workers, but less than 90 percent of workers), rose, in total, about 12 percent. The union wage effect was one third larger (16 percent) than the full impact of four years of historically rapid real wage growth.

Over the same boom period in the 1990s, employer-provided health and pension coverage among the bottom fifth of workers rose only about three percentage points for health insurance (up 3.2 percentage points) and pensions (up 2.7 percent) --about one-eighth of the impact of unionization on health and pension coverage among low-wage occupations analyzed here.

These union effects are particularly impressive given the widespread belief that many of the jobs analyzed here are inherently incapable of providing decent pay and benefits.

Our findings demonstrate that workers in low-wage occupations who are able to bargain collectively earn more and are more likely to have benefits associated with good jobs. We conclude that better protection of workers' right to unionize would help improve the quality of low-wage jobs.

\footnotetext{
1 An employer- or union-sponsored plan where the employer paid at least a portion of the insurance premium.

${ }^{2}$ The employer- or union-provided pension that may or may not include an employer contribution to the plan.
} 


\section{Introduction}

In recent decades, many politicians, policy-makers, and even anti-poverty advocates have come to the view that low-wage jobs are an inevitable part of a growing economy. Some go so far as to celebrate the growth of low-wage work and low-wage employers like Wal-Mart as part of a "progressive success story" benefiting "workers, consumers, and owners of capital" by lowering prices and increasing productivity. ${ }^{3}$

Liberals and centrists who hold this view often acknowledge that low-wage work "does not pay enough for a family to live the dignified life Americans have come to expect and demand." To address this problem, they promote increases in public spending on publicly-funded employment benefits in order to "make work pay." ${ }^{4}$ These benefits, which are typically targeted to parents in low-income households, include ones that supplement cash income (the Earned Income Tax Credit), provide health insurance (Medicaid and SCHIP, which covers children), and offer direct assistance for other work expenses, that, for higher-income workers, are subsidized in part through the tax code (such as child care and transportation). During the 1990s, the states and the federal government did expand some of these kinds of benefits, while at the same time reducing the availability of income supplements (most notably, the now-defunct Aid to Families with Dependent Children (AFDC) and its replacement Temporary Assistance to Needy Families (TANF). ${ }^{5}$

According to the conventional view, the meager pay and limited benefits of low-wage jobs reflect the limitations of the workers holding these jobs, and increases in inequality and declines in middleclass jobs are explained by "a large increase in the return for skills over the last decades .... [that is] driven largely by technology ... [and] globalization." Proponents of this approach typically argue that "the most fundamental solution" to the problem of increasing inequality "is to invest in the education and training necessary to ensure that all workers can succeed in the global economy." ${ }^{6}$

Generally absent from this approach is any focus on low-wage jobs themselves (a notable exception is support for the minimum wage). While some proponents of the make-work-pay strategy are simply agnostic on labor-market reform, others openly oppose reforms they characterize as "intervening" in the labor market. ${ }^{7}$ A greatly diminished role for labor-market institutions in promoting shared prosperity marks a significant difference between the recent decades of rising inequality in the United States and the immediate post-World War II period of mass upward mobility, when institutional concerns were at the forefront. ${ }^{8}$

Education, training, and in-work supports offer genuine benefits to low-wage workers. Where these policies are sufficiently generous and accessible, they can make a substantial contribution to

\footnotetext{
${ }^{3}$ See, for example, Furman (2005).

4 The two preceding quotes are from Furman (2005). Some conservatives endorse a variant of this make-work-pay agenda, see, for example, Douthat and Salam (2005) and Haskins and Sawhill (2007).

${ }^{5}$ Waller and Fremstad (2006).

${ }^{6}$ Furman (2005), emphasis added.

${ }^{7}$ In "New Rules; Here Come the Economic Populists," in the New York Times, November 26, 2007, Louis Uchitelle, for example, quotes Peter Orszag, then head of the centrist Hamilton Project: "You pay a steep economic cost when you adopt market interventions."

${ }^{8}$ See Levy and Temin (2007): "...the current trend toward greater inequality in America is primarily the result of a change in economic policy that took place in the late 1970s and early 1980s. The stability in income equality where wages rose with national productivity for a generation after the Second World War was the result of policies that began in the Great Depression with the New Deal and were amplified by both public and private actions after the war. This stability was not the result of a natural economy; it was the result of policies designed to promote it."
} 
improving the quality of life of low-wage workers. ${ }^{9}$ Nevertheless, an exclusive focus on low-wage workers rather than the failings of low-wage jobs has important limitations. The reality is that mobility out of low-wage work is surprisingly low. ${ }^{10}$ Most low-wage workers are adults already well into their work lives, not young people just starting out their careers. ${ }^{11}$ Recent research suggests that growth in low-wage (and very high-wage) jobs outpaced growth in middle-wage jobs in the $1990 \mathrm{~s}^{12}$ and projections of future employer demand suggests that most of today's low-wage occupations will be at least as numerous in the future as they are today. ${ }^{13}$

Over 40 million jobs in the United States-about one in three-pay low wages. ${ }^{14}$ Even though expanding low-wage workers' access to high-quality skills training and education will help more lowwage workers to move into better jobs, low-wage jobs constitute such a large share of jobs in the economy that expanded access to training and education provide only one prong of a multi-pronged strategy necessary to maintain and expand the middle class.

An approach based on strengthening labor-market institutions complements, rather than conflicts with, the make-work-pay agenda. Key elements of such an approach include enforcing ${ }^{15}$ and enhancing existing labor standards including the minimum wage and other wage and hour standards, as well as establishing new basic labor standards, such as minimum guarantees of paid vacation, sick pay, and parental leave. An important variation of this strategy, which we analyze here, is to allow greater unionization to promote better pay, benefits, and working conditions in existing low-wage jobs, primarily through improving the bargaining power of low-wage workers. ${ }^{16}$

Given the prevalence of low-wage jobs without benefits in our labor market, and the likelihood that these sectors will grow rather than decline, some attention to the strategy of improving the jobs is critical to strengthening our economy and communities. Unless these jobs are improved, our nation will permanently consign a large portion of workers in the United States to bad jobs.

${ }^{9}$ For the most part, training, education, and in-work benefits for low-wage workers, however, are not sufficiently generous or accessible. For example, between 1985 and 2003, funding for job training and related worker investment programs administered by the U.S. Department of Labor declined, after adjusting for inflation, by 29 percent (Spence and Kiel, 2003) Moreover, the United States spends a much smaller share of its GDP on training and employment programs than do nearly all other OECD nations (LaLonde, 2003). Except in a few states, child-care assistance is not consistently available for all low-wage workers who meet income eligibility guidelines.

${ }^{10}$ Osterman (1999), for example, found that about half of men in the bottom earnings quintile in 1979 were still there in 1995. Interestingly, intergenerational income mobility consistently appears to be higher elsewhere than it is in the United States; see, Blandon (2004), Hertz (2006), Schmitt and Zipperer (2006), and Solon (2002).

11 If we define low-wage workers as those earning less than two-thirds of the median wage, combined data from the Current Population Survey (CPS), for example, show that over 60 percent of low-wage workers were over the age of 25; just over 40 percent were at least 35 years old.

12 Autor, Katz, and Kearney (2006).

${ }^{13}$ Hecker(2005) reports BLS predictions that through 2014 the second-biggest percentage and second-biggest numerical gains in employment by broad occupation category will be in "service occupations" including "food preparation and serving related," "health care support," "personal care and service," "building and grounds cleaning and maintenance," and "protective service."

${ }^{14}$ Boushey, Fremstad, Gragg, and Waller (2007).

15 For an excellent discussion of enforcement issues in the low-wage labor market, see Bernhardt, McGrath and DeFilippis (2007).

${ }^{16}$ The link to bargaining power underscores the connection between raising unionization rates in low-wage occupations and the emphasis that others have correctly placed on the importance for low-wage workers of sustained, low unemployment. See, for example, Bernstein and Baker (2003) and Mishel, Bernstein, and Allegretto (2006), among others. 
This paper examines the impact of unionization on the pay and benefits in 15 important low-wage occupations. ${ }^{17}$ The data suggests that even after controlling for differences between union and nonunion workers, union representation substantially improves the pay and benefits offered in what are otherwise low-paying occupations. ${ }^{18}$ On average, in the low-wage occupations analyzed here, unionization raised workers' wages by just over 16 percent --about $\$ 1.75$ per hour-- compared to similar, but non-union, workers. The union impact on health-insurance and pension coverage in low-wage jobs was even bigger. Union workers in low-wage occupations were 25 percentage points more likely to have employer-provided health insurance, ${ }^{19}$ as well as 25 percentage points more likely to be in an employer-provided pension. ${ }^{20}$

These union effects are large by any measure. For example, between 1996 and 2000, a period of sustained low unemployment that helped to produce the best wage growth for low-wage workers in the last three decades, the real wage of 10th percentile workers (who make more than 10 percent of workers, but less than 90 percent of workers), saw their wages rise, in total, about 12 percent. The union wage effect was one third larger (16 percent) than the full impact of four years of historically rapid real wage growth. Over the same boom period in the 1990s, health and pension coverage among the bottom fifth of workers rose only about three percentage points for health insurance (up 3.2 percentage points) and pensions (up 2.7 percent), about one-eighth of the impact of unionization on health and pension coverage among low-wage occupations analyzed here. The union effects are particularly impressive given the widespread belief that many of the jobs analyzed here are inherently incapable of providing decent pay and benefits.

\section{Defining Low-Wage Occupations}

We analyze 15 low-wage occupations as defined by the "Standard Occupational Classification 2000" system used in the Current Population Surveys for 2004, 2005, and 2006. The specific occupations we selected were the 15 lowest-paid occupations meeting the following criteria: first, in order to ensure a reasonable sample size for analysis, the occupation had to meet or exceed a minimum size requirement equal to roughly 0.25 percent of the total workforce over the combined three-year period; second, in order to ensure that we have a reasonable base for measuring union effects within each group, the unionization rate had to be at least five percent in selected occupations; finally, we used the median wage for non-union workers as the benchmark wage for ordering occupations from lowest to highest.

We made only one deviation from the above formula: we combined the two lowest-wage occupations "combined food preparation and serving workers, including fast food" and "food

\footnotetext{
17 Together, these occupations account for about 15.3 percent of total U.S. employment. Since these occupations have been selected first and foremost because they pay the lowest wages in the economy, we believe that our results are broadly representative of the potential impact of unionization on other low-wage occupations not analyzed here.

18 Earlier research finds substantial union effects on wages and benefits for workers overall (see Blanchflower and Bryson, 2007). Research has paid less attention, however, to low-wage work. Zuberi (2006) compared differences in living standard and working conditions for hotel workers in Seattle and Vancouver and concluded that "union membership provides hotel workers better benefits, improved job security, and better working conditions" and that "in Vancouver, the rates of unionization in the hotel industry are high enough that they create a union wage effect that also increases the wages and benefits offered to employees in non-unionized hotels." (p. 66)

${ }^{19}$ An employer- or union-sponsored plan for which the employer paid at least a portion of the insurance premium. To be clear, we believe that universal health care where eligibility is not connected to an individual's employment status or particular employer would be a substantial improvement over the current system, which leaves many workers and their children without health insurance.

${ }^{20}$ The employer- or union-provided pension may or may not include an employer contribution to the plan.
} 
preparation workers," which are conceptually closely related and both of which separately met our selection criteria. (For further details on the data analyzed here, see the Data Appendix.)

The final list of low-wage occupations appears in Table 1. The lowest-paid occupation is food preparation workers (the combined category mentioned above), which had a median, non-union wage of just $\$ 7.80$ per hour over the period 2004-2006. ${ }^{21}$ This figure indicates that half of the workers in this occupation earn $\$ 7.80$ or less per hour. Cashiers are the next-lowest paid occupation with a median hourly wage of $\$ 8.00$ per hour. Other low-wage occupations, with medians as high as \$10.94 per hour include: cafeteria workers, child-care workers, cooks, housekeeping cleaners, homecare aides, janitors, ground maintenance workers, nurses aides and home-health aides, teachers' assistants, and security guards.

TABLE 1

Hourly wages and union share in 15 low-wage occupations, 2003-2006

\begin{tabular}{|c|c|c|c|c|c|c|c|}
\hline \multirow[b]{2}{*}{ Occupation } & \multirow{2}{*}{$\begin{array}{r}\text { Union share } \\
\text { (percent) }\end{array}$} & \multicolumn{2}{|c|}{$\begin{array}{l}\text { Median hourly wage } \\
(2006 \$)\end{array}$} & \multicolumn{2}{|c|}{$\begin{array}{l}\text { Health-insurance } \\
\text { (percent) }\end{array}$} & \multicolumn{2}{|c|}{$\begin{array}{l}\text { Pension } \\
\text { (percent) }\end{array}$} \\
\hline & & \multicolumn{2}{|c|}{ Union Non-union } & \multicolumn{2}{|c|}{ Union Non-union } & \multicolumn{2}{|c|}{ Union Non-union } \\
\hline Food preparation workers & 8.2 & 10.32 & 7.80 & 44.5 & 21.6 & 37.8 & 13.5 \\
\hline Cashiers & 6.8 & 10.32 & 8.00 & 55.4 & 18.1 & 40.1 & 11.8 \\
\hline Cafeteria workers & 9.2 & 10.48 & 8.00 & 54.2 & 19.1 & 39.1 & 16.3 \\
\hline Child-care workers & 5.9 & 11.00 & 8.27 & 56.6 & 13.7 & 61.7 & 8.3 \\
\hline Cooks & 5.1 & 11.67 & 8.54 & 55.5 & 18.1 & 53.4 & 14.0 \\
\hline Housekeeping cleaners & 7.2 & 11.44 & 8.78 & 71.7 & 22.6 & 56.5 & 15.4 \\
\hline Home-care aides & 10.7 & 9.87 & 9.00 & 49.4 & 21.8 & 32.0 & 17.3 \\
\hline Packers and packagers & 11.7 & 11.47 & 9.33 & 63.1 & 36.1 & 74.9 & 24.5 \\
\hline Janitors & 18.1 & 13.86 & 9.60 & 74.9 & 37.8 & 67.3 & 28.0 \\
\hline Grounds maintenance workers & 6.3 & 15.35 & 9.65 & 55.9 & 24.7 & 78.5 & 16.3 \\
\hline Nursing and home-health aides & 13.8 & 11.52 & 10.00 & 70.9 & 36.6 & 57.6 & 25.9 \\
\hline Stock clerks & 11.6 & 13.54 & 10.00 & 66.9 & 40.1 & 53.5 & 30.5 \\
\hline Teachers' assistants & 35.2 & 13.00 & 10.25 & 53.3 & 35.3 & 73.0 & 41.3 \\
\hline Laborers and freight workers & 19.1 & 13.87 & 10.32 & 71.1 & 43.0 & 60.1 & 35.0 \\
\hline Security guards & 12.9 & 14.86 & 10.94 & 63.7 & 47.3 & 54.8 & 27.3 \\
\hline All low-wage occupations & 12.0 & 12.39 & 9.03 & 63.3 & 27.6 & 59.8 & 21.2 \\
\hline All occupations & 13.5 & 19.85 & 14.45 & 77.7 & 52.3 & 76.5 & 44.7 \\
\hline $\begin{array}{l}\text { Notes: CEPR analysis of CEPR } \\
\text { of March Current Population Su } \\
\text { to participation in an employer- } \\
\text { refers to participation in an emp } \\
\text { further details on sample. Healt }\end{array}$ & $\begin{array}{l}\text { union-spons } \\
\text { yer-sponsored } \\
\text { ind pension ce }\end{array}$ & $\begin{array}{l}\text { red plan whe } \\
\text { plan, with o } \\
\text { verage refer }\end{array}$ & $\begin{array}{l}\text { Surve } \\
\text { membe } \\
\text { he emp } \\
\text { thout el } \\
003-20\end{array}$ & $\begin{array}{l}r \text { pays so } \\
\text { yer contı } \\
\text { wages ref }\end{array}$ & all o & $\begin{array}{l}\text { UNIC } \\
\text { insura } \\
\text { emium. } \\
\text { ndix Ts }\end{array}$ & $\begin{array}{l}\text { xtract } \\
\text { fers } \\
\text { ion } \\
\text { or }\end{array}$ \\
\hline
\end{tabular}

${ }^{21}$ These and all dollar figures reported in the report are in inflation-adjusted 2006 dollars. 


\section{Unionized Low-Wage Jobs Pay Better and Are More Likely to Provide Benefits}

In the workforce as a whole, about 13.5 percent of workers are unionized (either a member of a union or represented by a union at their workplace). As Table 1 demonstrates, unionized workers typically earn substantially more than their non-union counterparts. In 2004-2006, the median unionized worker earned about $\$ 19.85$ per hour, compared to $\$ 14.45$ per hour for the median nonunion worker. Unionized workers were also much more likely to have health insurance (77.7 percent) than non-union workers (52.3 percent), and more likely than non-union workers to have a pension plan (76.5 percent, compared to 44.7 percent).

Unionization rates vary widely among the low-wage occupations analyzed here, from barely five percent for cooks (5.1 percent) to over one-third of teachers' assistants ( 35.2 percent). Several other low-wage occupations have unionization rates that exceed the national average of 13.5 percent: laborers and freight workers (19.1 percent), janitors (18.1), and nursing and home-health aides (13.8). Most of the low-wage occupations, however, are less heavily unionized than the national average.

As is the case for the workforce as a whole, unionized workers in low-wage occupations earn substantially higher salaries and are much more likely to have health insurance and a pension plan than are non-union workers in the same occupations. Combining all 15 low-wage occupations, the median union worker (\$12.39) makes more than three dollars per hour more than the median nonunion worker (\$9.03). Overall, workers in low-wage occupations are less likely to have health insurance and pensions than the average worker in the total economy, but unionized workers in these same low-wage occupations have huge advantages over their non-union counterparts. Almost two-thirds of unionized workers (63.3 percent) in low-wage occupations have health insurance, compared to just over one-fourth of non-union workers (27.6 percent) in the same occupations. For pension plans, the union gap is even larger: 59.8 percent of unionized workers in low-wage occupations have a pension, compared to just 21.2 percent of their non-union counterparts.

A similar pattern of higher wages and much greater health-insurance and pension coverage repeats itself in every one of the low-wage occupations. Across the occupations in Table 1, the union effect appears to be consistently larger in economic terms for health and pension coverage than it is for wages. Unionized workers in several low-wage occupations, for example, have health-insurance coverage rates close to the average for the economy as a whole $(77.7$ percent for the economy as a whole, compared with 74.9 percent for janitors, 71.7 percent for housekeeping cleaners, 71.1 percent for laborers and 70.9 percent for nursing and home-health aides).

The data in Table 1, however, may overstate the union effect because union workers may be more likely to have characteristics associated with higher wages such as being older or having more formal education. In Table 2 , we present a second set of results using standard regression techniques to control for these and other potential differences in the unionized and non-union workforces. ${ }^{22}$ Controlling for these other effects does reduce the wage effect, but has relatively little impact on the large union-nonunion gap in health-insurance and pension coverage. After we control for workers' characteristics, the union wage premium for workers in low-wage occupations is 16.4 percent or about $\$ 1.75$ per hour. Among low-wage occupations, the union advantage with respect to healthinsurance and pension coverage also remains large, with unionized workers in low-wage industries

\footnotetext{
${ }^{22}$ We control for age, education, gender, race, state of residence, and two-digit industry. The wage regressions use ordinary least squares; the health-insurance and pension regressions are probits.
} 
about 25 percentage points more likely than others in the same occupations to have health-insurance or a pension.

\section{TABLE 2}

Regression-adjusted union wage, health, and pension premiums in 15 low-wage occupations, 2003-2006

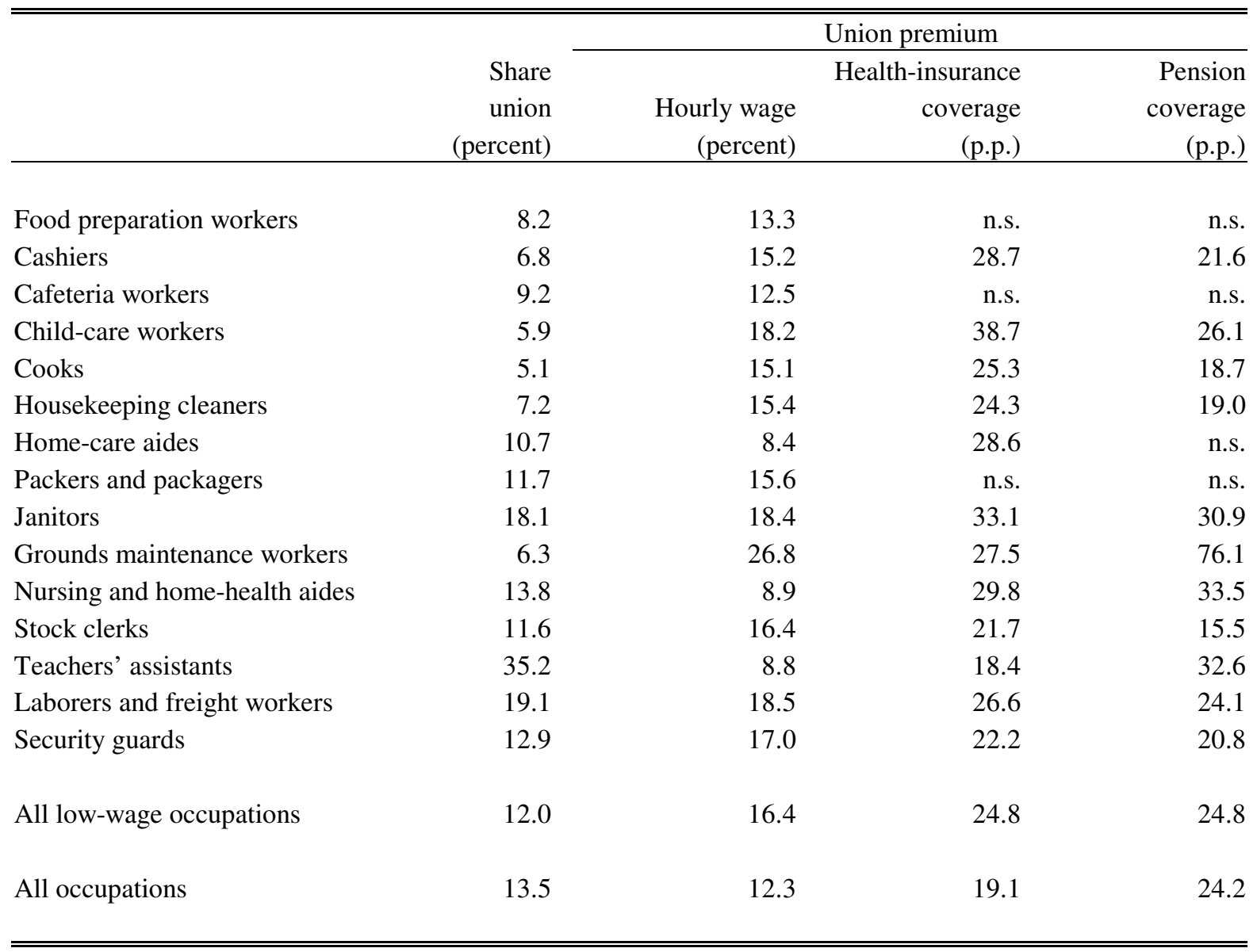

Notes: All regressions include controls for age, education, gender, race, state, and two-digit industry.

Union wage premiums in percent are converted from log points; all are statistically significant at at

least the one-percent level. Union-health insurance and pension coverage figures are the percentage-point (p.p.) increases associated with union coverage or membership; all estimates are significant at at least the five-percent level, except those marked not significant (n.s.). See Appendix Table for further details about sample.

Health and pension coverage refer to 2003-2005; wages refer to 2004-2006.

The union wage premium and health-insurance and pension advantages are consistent across all the low-wage occupations for which we have statistically significant results. The regression-controlled union wage premium varies from about 8 percent for home-care aides, teachers' assistants, and nursing and home-health aides, to almost 27 percent for ground maintenance workers, with the premium around 15 percent for most of the remaining occupations. The union effect on healthinsurance coverage is in the range of 20 to 30 percentage-points for almost all of the occupations in the sample; the effect is slightly smaller for teachers' assistants (18.4 percentage points) and higher for child-care workers (38.7 percentage points). The impact of unions is not statistically significant for three of the 15 occupations (food preparation workers, cafeteria workers, and packers and packages); these results, however, may reflect the small sample size for two of these three occupations (see Appendix Table). The union effect on pension coverage is broadly similar to the 
results for health insurance, with workers in most occupations seeing their likelihood of having a pension rise between 20 and 30 percentage points if they are in a union.

\section{Low-Wage Jobs Improved by Worker Rights}

The National Labor Relations Act, enacted by Congress in 1935, declares that it is the policy of the United States to "encourag[e] the practice and procedure of collective bargaining and ...protect the exercise by workers of full freedom of association, self-organization, and designation of representatives of their own choosing, for the purpose of negotiating the terms and conditions of their employment or other mutual aid or protection." 23 Our findings demonstrate that the exercise of these basic and longstanding rights by employees results in better wages - about 16 percent higher - and benefits - a 25 percentage-point higher probability of having health insurance or a pension - for workers in 15 low-wage occupations.

Our findings complement other research suggesting that unions reduce employee turnover and wage inequality, and increase access to sick pay and annual leave. ${ }^{24}$ Taken together, these positive effects of collective bargaining-due in an important part to the role that unionization plays in giving employees a voice in their workplaces-argue that unionization is a key element of an effective strategy to build a stronger and more inclusive economy.

In this sense, unionization does more than boost wages. It also promotes social inclusion-the ability for workers, even those in low-wage occupations, to participate fully in the social and economic life of their communities. ${ }^{25}$

\footnotetext{
2329 U.S.C. $\$ 151$

${ }^{24}$ Research also suggests that collective bargaining probably has little effect, and may have a positive effect, on productivity. Freeman (2006): “... I regard the evidence as more favorable to a positive union effect ... but agree that the strongest conclusion from this research is that there is a lot of variation in estimated union effects." (p. 625)

25 As defined in Boushey, Bronosky, Fremstad, Gragg, and Waller (2007), social inclusion is based on the belief that we all fare better when no one is left to fall too far behind and the economy works for everyone.
} 


\section{References}

Autor, David, Lawrence Katz, and Melissa Kearney. 2006. "The Polarization of the U.S. Labor Market," NBER Working Paper No. W11986, January.

Bernhardt, Annette, Siobhan McGrath and James DeFilippis. 2007. Unregulated Work in the Global City: Employment and Labor Law Violations in New York City. New York: Brennan Center for Justice, New York University School of Law.

Bernstein, Jared, and Dean Baker. 2003. The Benefits of Full Employment: When Markets Work for People. Washington, DC: Employment Policy Institute.

Blanchflower, David and Alex Bryson. 2007. "What Effect Do Unions Have on Wages Now and Would Freeman and Medoff Be Surprised?," in Bennett, James and Bruce Kaufman (eds.), What Do Unions Do: A Twenty Year Perspective, Transaction Publishers.

Blanden, Jo. 2004. "International Evidence on Inter-generational Mobility," London: London School of Econmics, Centre for Economic Performance, unpublished paper.

Boushey, Heather, Natalie Bronosky, Shawn Fremstad, Rachel Gragg, and Margy Waller. "Social Inclusion for the United States." Washington, DC: Inclusion/The Mobility Agenda. http://www.inclusionist.org/files/socialinclusionusa.pdf

Boushey, Heather, Shawn Fremstad, Rachel Gragg, and Margy Waller. 2007. "Understanding LowWage Work in the United States," Washington, DC: Inclusion/The Mobility Agenda. http://www.inclusionist.org/files/lowwagework.pdf

Douthat, Ross and Reihan Salam. 2005. “The Party of Sam's Club: Isn't It Time that the Republicans Did Something for their Voters?,” The Weekly Standard, November 14. http://www.weeklystandard.com/Content/Public/Articles/000/000/006/312korit.asp?pg=1

Freeman, Richard. 2007. "What Do Unions Do? The 2004 M-Brane Stringtwister Edition," in Bennett, James and Bruce Kaufman (eds.), What Do Unions Do: A Twenty Year Perspective, Transaction Publishers.

Furman, Jason. 2005. "Wal-Mart: A Progressive Success Story," Washington, DC: Center for American Progress. http://www.americanprogress.org/kf/walmart_progressive.pdf.

Haskins, Ron and Isabel Sawhill. 2007. "Ending Poverty in America: Using Carrots and Sticks," The American Prospect (May).

Hecker, Daniel E. 2005. "Occupational employment projections to 2014," Montbly Labor Review, (November), pp. 70-101.

Hertz, Tom. 2006. "Understanding Mobility in America," Washington, DC: Center for American Progress. http://www.americanprogress.org/issues/2006/04/Hertz_MobilityAnalysis.pdf

LaLonde, Robert J. 2003. "Employment and Training Programs in Means-tested Transfer Programs" in Feldstien, Martin and Robert Moffitt, (eds.) Means Tested Transfer Programs in the U.S., Chicago: University of Chicago Press. 
Levy, Frank and Peter Temin. 2007. "Inequality and Institutions in Twentieth Century America," NBER Working Paper 07-17.

Mishel, Lawrence, Jared Bernstein, and Sylvia Allegretto. 2006. The State of Working America 20062007. Ithaca, New York: Cornell University Press.

Osterman Paul. 2000. Securing Prosperity: The American Labor Market: How It Has Changed and What to Do About It. Princeton University Press.

Schmitt, John and Ben Zipperer. 2006. "Is the U.S. a Good Model for Reducing Social Exclusion in Europe?" Center for Economic and Policy Research Briefing Paper.

Schmitt, John and Ben Zipperer. 2007. "Dropping the Ax: Illegal Firings During Union Election Campaigns," Center for Economic and Policy Research Briefing Paper.

Solon, Gary. 2002. "Cross-Country Differences in Intergenerational Earnings Mobility," Journal of Economic Perspectives, vol 16, no. 3 (Summer), pp. 59-66.

Spence, Robin and Brendan Kiel. 2003. "Skilling the American Workforce "On the Cheap": Ongoing Shortfalls in Federal Funding for Workforce Development," The Workforce Alliance. http://www.workforcealliance.org/atf/cf/\%7B93353952-1DF1-473A-B1057713F4529EBB $\% 7 \mathrm{D} /$ twa-funding-analysis-09.pdf

Waller, Margy and Shawn Fremstad. 2006. "New Goals and Outcomes for Temporary Assistance: State Choices in the Decade after Enactment," Washington, DC: The Brookings Institution. http://www.brookings.edu/metro/pubs/20060816_tanf.htm.

Zuberi, Dan. 2006. Differences that Matter: Social Policy and the Working Poor in the United States and Canada. Ithaca: ILR Press. 


\section{Data Appendix}

In order to have a sample that is sufficiently large to analyze fairly fine occupations, our analysis combines data from three consecutive years of the Current Population Survey (CPS), a nationally representative monthly survey of about 60,000 households. For wage-related data, we use the 2004 to 2006 merged Outgoing Rotation Group (ORG) from the CPS. The ORG is a series of questions about the respondent's current job, asked of one-quarter of the monthly participants in the CPS. For health- and pension-related data, we use the March supplement to the CPS for 2004 to 2006. The March CPS survey asks respondents about their health- and pension-coverage in the preceding calendar year, so the health and pension data in the report refers to coverage during the calendar years 2003, 2004, and 2005. (The wage data refer to calendar years, 2004, 2005, and 2006; in both cases, we use the most recent data available as we write this report.)

\section{Health}

The March CPS asks whether an individual was covered by an employer-provided health-insurance plan and, if so, whether the employer paid all, part, or none of the premiums for that plan. We treat workers as having health-insurance coverage if their employer (or union) offered a plan and the employer paid at least part of the premiums associated with the plan.

\section{Pension}

The March CPS asks whether an individual's employer participated in an employer-sponsored pension plan. Unfortunately, the survey does not distinguish between defined-contribution and defined-benefit plans and does not ask if the employer makes a contribution to the plan. We treat workers as having pension coverage if their employer offered a retirement plan, whether or not the employer made a contribution to that plan.

\section{Union}

The CPS ORG asks workers if they are a member of, or represented by, a union at their current job. We define a union worker as any worker who says that he or she is a member of or represented by a union. Unfortunately, the March CPS does not ask workers about their union status during the preceding calendar year. We use workers' union status in their current job in March of each year as a proxy for their union status in the preceding calendar year. Using workers' status in March has two drawbacks for our analysis. First, since we must rely on union status in March, which comes from the ORG for the same month, we are limited to only one-fourth of the full March CPS sample --the fourth of the full monthly sample that also participated in the ORG. The smaller sample reduces the precision of our estimates of the union effect on health and pension, making it more difficult for us to find a statistically significant union effect if one exists. Second, using union status in March as a proxy for union status in the preceding year introduces measurement error into the union variable in the health and pension regressions. Measurement error is likely to be more problematic in this context because turnover is generally higher than average in low-wage occupations. Measurement error will bias the coefficient of the variable measured with error toward zero, making it less likely that we will find a statistically significant union effect if there is one. 


\section{Data}

All data and programs used to produce this analysis are available upon request. The underlying CEPR extracts of the CPS-ORG analyzed in this paper are available to download from http://ceprdata.org.

APPENDIX TABLE

Occupational codes in Tables 1 and 2 and sample sizes for regressions in Table 2

\begin{tabular}{|c|c|c|c|c|c|}
\hline \multirow[b]{3}{*}{ Full occupation title } & \multirow{3}{*}{$\begin{array}{r}\text { SOC } 2000 \\
\text { code }\end{array}$} & \multirow{3}{*}{$\begin{array}{l}\text { CPS } \\
\text { code }\end{array}$} & \multicolumn{3}{|c|}{ Sample size } \\
\hline & & & \multirow{2}{*}{$\frac{\text { ORG }}{\text { Wages }}$} & \multicolumn{2}{|c|}{ March } \\
\hline & & & & Health & Pension \\
\hline Combined food prep and serving workers, incl. fast food & $35-3021$ & 4050 & \multirow[t]{2}{*}{4,258} & \multirow[t]{2}{*}{428} & \multirow[t]{2}{*}{378} \\
\hline Food preparation workers & $35-2021$ & 4030 & & & \\
\hline Cashiers & $41-2010$ & 4720 & 12,411 & 1,433 & 1378 \\
\hline Dining room and cafeteria attendants and bartender helpers & $35-9011$ & 4130 & 1,560 & 116 & 121 \\
\hline Child care workers & $39-9011$ & 4600 & 3,679 & 395 & 363 \\
\hline Cooks & $35-2010$ & 4020 & 7,605 & 885 & 872 \\
\hline Maids and housekeeping cleaners & $37-2012$ & 4230 & 5,532 & 581 & 560 \\
\hline Personal and home care aides & $39-9021$ & 4610 & 2,681 & 249 & 209 \\
\hline Packers and packagers, hand & $53-7064$ & 9640 & 1,710 & 129 & 73 \\
\hline Janitors and building cleaners & $31-201 X$ & 4220 & 8,553 & 955 & 950 \\
\hline Grounds maintenance workers & $37-3010$ & 4250 & 3,896 & 322 & 317 \\
\hline Nursing, psychiatric, and home health aides & $31-1010$ & 3600 & 7,769 & 902 & 908 \\
\hline Stock clerks and order fillers & $43-5081$ & 5620 & 5,880 & 703 & 701 \\
\hline Teacher assistants & $25-9041$ & 2540 & 4,267 & 520 & 526 \\
\hline Laborers and freight, stock, and material movers, hand & $53-7062$ & 9620 & 7,364 & 855 & 845 \\
\hline Security guards and gaming surveillance officers & $33-9030$ & 3920 & 3,252 & 302 & 290 \\
\hline All low-wage occupations & All above & All above & 80,417 & 9,634 & 9,634 \\
\hline All occupations & All & All & 533,288 & 64,509 & 64,509 \\
\hline
\end{tabular}

Notes: "SOC 2000" is the Standard Occupational Classification 2000; for details about the contents of each group, see http://www.bls.gov/soc/socguide.htm. "CPS code" is the occupational code in the 2004-2006 CPS (March and ORG) analyzed here. The first occupations in this table have been combined in the analysis used in Tables 1 and 2 and elsewhere in the paper; the sample sizes refer to the combined sample. The March CPS sample is smaller than the ORG sample for two reasons: (1) the CPS ORG is one-fourth of the full CPS for 12 months, while the March CPS is the full CPS for only one month; and (2) the March CPS has union affiliation in the current month for only one fourth of the participants in the survey that month. Union affiliation data from the March CPS refer to the respondent's job in March of each year, while health and pension benefits refer to the respondent's main job in the preceding calendar year, which means the estimates in Tables 1 and 2 are measured with some error; the measurement error will reduce the reliability of the estimates of the union-nonunion gap, but will not bias the estimates of the union effect in either direction. 